Claremont Colleges

Scholarship@ Claremont

All HMC Faculty Publications and Research

HMC Faculty Scholarship

$1-1-1998$

\title{
Design and Design Centers in Engineering Education
}

Clive L. Dym

Harvey Mudd College

\section{Recommended Citation}

C. L. Dym, "Design and Design Centers in Engineering Education," Artificial Intelligence for Engineering Design, Analysis and Manufacturing, 12 (1), 43-46, January 1998. DOI: 10.1017/S0890060498121030

This Article is brought to you for free and open access by the HMC Faculty Scholarship at Scholarship @ Claremont. It has been accepted for inclusion in All HMC Faculty Publications and Research by an authorized administrator of Scholarship @ Claremont. For more information, please contact scholarship@cuc.claremont.edu. 


\title{
AI EDAM
}

http://journals.cambridge.org/AIE

Additional services for Al EDAM:

Email alerts: Click here

Subscriptions: Click here

Commercial reprints: Click here

Terms of use : $\underline{\text { Click here }}$

\section{Design and design centers in engineering education}

\author{
CLIVE L. DYM
}

Al EDAM / Volume 12 / Issue 01 / January 1998, pp 43 - 46

DOI: null, Published online: 08 September 2000

Link to this article: http://journals.cambridge.org/abstract S0890060498121030

How to cite this article:

CLIVE L. DYM (1998). Design and design centers in engineering education. AI EDAM, 12, pp 43-46

Request Permissions : $\underline{\text { Click here }}$ 


\section{POSITION PAPER \\ Design and design centers in engineering education}

CLIVE L. DYM

Department of Engineering, Harvey Mudd College, 301 E. 12th St., Claremont, CA 91711, U.S.A.

(Received June 11, 1997; Revised September 9, 1997; AcCepted August 8, 1997)

\section{OPENING NOTES}

This paper is intended to be the opening salvo of the workshop, Computing Futures in Engineering Design (Dym, 1997). Thus, I want to take this privileged moment to ask you to think with me about the role of design in engineering. In particular, I want to reflect upon how design is articulated and how design is taught; about the role of design in engineering education and in the practice of engineering; and about the role that could be played locally and, perhaps, nationally by a center devoted to design education. Because I teach here at Harvey Mudd College (HMC), and because most of you are visitors, I will place my remarks in our context by telling you about what we do here and how that doing has shaped my thinking.

\section{THE HARVEY MUDD ENGINEERING AND CLINIC PROGRAMS}

Let me begin by talking about the engineering program at HMC, where for more than three decades we have offered an interdisciplinary engineering education that strongly emphasizes design and the experience of students working in teams on industrially sponsored "Engineering Clinic" design and development projects (Phillips \& Gilkeson, 1991; Harvey Mudd College Catalog, 1996-1998). The undergraduate engineering curriculum at HMC has three "stems": system engineering, which is a set of three courses that focus on modeling and manipulating lumped-element models of physical systems; engineering science, which focuses on introductory courses in mechanics, thermodynamics, materials, and electrical and computer engineering; and design, which includes a series of courses beginning with a freshman design course (Dym, 1994a), through a remarkable sophomore course, and culminating in the Clinic projects in the junior and senior years (Phillips \& Gilkeson, 1991). The

Reprint requests to: Clive L. Dym, Department of Engineering, Harvey Mudd College, 301 E. 12th St., Claremont, CA 91711, U.S.A. E-mail: Clive_Dym@hmc.edu sophomore course requires the design and manufacture of tools, such as a hammer and a screwdriver, and the completion of detailed design projects requiring experimental determination of design parameters. The three stems of our engineering curriculum are unified by recognizing that engineers typically design systems; that such design requires good models of physical systems; and that design is the distinguishing, central activity of engineering (Simon, 1981).

I also want you to know that Engineering Clinic celebrated its 30th birthday in May 1994. Clinic was introduced into the HMC engineering program in 1963, quite a few years before the advent of the "Capstone Design Course" in the ABET criteria (Phillips, 1994). Many other engineering (and liberal arts!) programs have adopted the Clinic idea in more recent years.

HMC's unique emphasis on the centrality of design and project work and its pioneering development of Clinic has, in other ways, paralleled some aspects of American engineering education. In particular, until relatively recently, much of what we expected students to take away from the design courses and from Clinic work was communicated implicitly, that is, by example rather than by formal articulation of techniques and methodologies. Thus, design was done, and project schedules and reports were produced. Recently, however, we have begun a conscious effort to make explicit what we mean and what we expect in design and in project management.

One change toward this new articulation came about with the redesign of HMC's freshman design course. Notwithstanding the argument that teaching design to freshmen is pointless-about which I will say more later-our experience strongly suggests that first-year students can do meaningful design work on interesting projects. They can also learn to use conceptual design tools, for example, objective trees, morphological charts, etc. (Dym, 1994a).

Interestingly, the ideas applied in the freshman design course are now clearly propagating through our curriculum, as can be clearly seen in student presentations of current Clinic work. Similarly, we have begun to make explicit ideas and tools relating to project and design management, for 
example, work-breakdown structures, activity networks, budgets, etc. Here, too, we see distinct gains both in the firstyear design course and in Engineering Clinic.

\section{WHAT ABOUT DESIGN?}

Design has been identified as the distinguishing mark of the professions, and especially of the profession of engineering (Simon, 1981). Design is also a subject that is constantly being studied and analyzed, in the context of engineering education and elsewhere. Yet engineering educators and practitioners continue to be quite concerned that design is neither properly taught nor adequately presented in engineering curricula. Recently there have been renewed calls for reconsiderations of design and its role in engineering education (Dixon, 1987, 1991a, 1991b; Dym, 1993; Evans, 1990; Shoup et al., 1993). Some of these calls have produced great controversy and debate (Dym, 1992a), ${ }^{1}$ and it is hard to say that there exists anything like a national consensus on design and design education-other than that everyone ought to be concerned about the state of design education.

A related theme is that engineering graduates lack adequate skills in some of the related "arts" of being an engineer, including working in teams, making presentations to a variety of audiences, and managing design and engineering projects (Lih, 1997). This set of issues is clearly important in today's business environment - the environment in which most engineers will work, and many of them in positions that are more than "technical."

The Accreditation Board for Engineering and Technology (ABET) has recognized some of these "environmental changes," as evidenced by their recent, dramatic revision of national accreditation standards (ABET's web site). One line of argument suggests that this state of affairs is largely the result of treating engineering education as engineering science, in a paradigm more accurately reflecting the world of academic research than that of the practice of engineering. In addition, it was often argued that design is experiential in nature, that "creativity cannot be taught," and that any intellectual discipline in design is imposed through scheduling and reporting requirements. Thus, and perhaps ironically, attempts to formalize and articulate a "scientific" theory of design were seen by design traditionalists as ruining engineering-design education because such an approach would turn design education into an abstract and sterile science, devoid of creativity and of practical experience (Mechanical Eng., 1991). Perhaps in reaction to this school of thought, engineering scientists and other "analytical types" felt that there was no "real" content to design education because traditional design teachers did not successfully articulate the intellectual content of design courses. Besides, for engineering scientists, no meaningful discipline of design could emerge until it was put into mathematical terms.

${ }^{1}$ See the spate of letters in Mechanical Engineering (1991) 113, in the April, May, June, July, and August issues in response to Dixon, J.R. $(1991 a, b)$
The role of management issues in engineering education, which is certainly related to our present concerns, has a similar history, buttressed by the oft-stated view that there simply is no room in an engineering curriculum for any more nontechnical courses.

The landscape is not quite so desolate, however. One effort devoted to improving the state of engineering education has been the set of coalitions sponsored by the National Science Foundation, for example, the Synthesis Coalition, which named the integration of a design backbone as one of its goals (Sheppard, 1996). Unfortunately, these coalitions have not produced the widespread reform - or even experimentationthat was once hoped for. There are other bright spots, but we want to stay with our present course of (1) thinking about how newer views of design can affect engineering curricula in the United States, and (2) pondering potential roles for a center of design education, with a primary-or even exclusivefocus on improving design education at all levels-undergraduate, graduate, and lifelong learning _ in contrast to the successful, research-oriented design centers at schools such as Carnegie Mellon and Stanford.

\section{WE SHOULD EMPHASIZE DESIGN THROUGHOUT THE ENGINEERING CURRICULUM}

Let me now make some brief observations about the current state of engineering education. Current curricula are, by design, very highly structured, typified by lengthy, serial, course sequences. They are organized within an engineering science model of engineering and delivered within academic settings that conform to the scientific research enterprise that has characterized college and university education since just after the Second World War. And the earliest_-and perhaps most critical-stages of our curricula are delivered by academic departments that may have agendas different than ours, the prime instance being mathematics. This may be the most telling point, because it is the apparent centrality of mathematics in the formative stages of engineering education that also most strongly points to a major intellectual failure of the engineering science model of engineering, that is, the notion that all serious engineering is done in the language of mathematics.

How many times do students confuse a mathematical model, an equation, or a formula with the real thing? (Of course, faculty never make such mistakes!) How often do students assume a problem can't be done because they "can't find the right equation"? Or worse, how often do they try to cram a problem into a formula-when the very phenomena or issues being modeled are not expressible in customary mathematical models? All because students believe that mathematics is the language of engineering! These days, of course, that language is "always" realizable in a nice piece of computer code or a really neat software package.

On a larger scale, how well do we communicate to our students the importance of knowing why they should be do- 
ing something, as opposed to their worrying about how to finish a well-structured problem set?

I would argue that a central failure of engineering education is that we don't teach enough languages, and in particular, we don't teach students the languages of design. Now part of this is an abstract argument about representation and the different ways of representing or expressing the tasks and problems of engineering (Dym, 1992b, 1994b, 1994c). But beyond the realm of abstract debate lies the notion that doing engineering, whether analysis or design, means using models that are expressed in a variety of representations or languages. The languages of engineering include mathematical or analytical models, but also verbal and textual statements, graphical representations, numbers, and the two "additional" representation languages of rules and objects or frames (Dym, 1994b). Moreover, we must be explicit and very clear that we are always using these several languages, performing different tasks of our engineering endeavor in the language most appropriate to that task, and, consequently, translating between those languages as the need arises.

What does this mean for a curriculum oriented to design, and thus for an engineering curriculum? It means that we should teach design from the beginning. I've noted that we teach a freshman design course here at HMC. Some believe that freshmen cannot do design and cannot be taught design because they have "such a limited background" that they cannot do any of the needed analyses to realize a final design. It is likely true that most freshmen could not literally design a stepladder step for strength or stiffness, nor could they design a transistor or an integrated circuit. However, most engineering freshmen are smart enough — and interested enough, given the chance - to take chances at putting together components, matching them in a systems-like approach, recognizing performance characteristics, and linking components accordingly. We have seen abundant evidence that first-year students can: comfortably ask a client about objectives so that they can translate them into performance specifications; learn to construct morphological charts to represent their design space; and compare different performance metrics to make choices that cannot be dictated by-or even expressed in-a formula from calculus or physics (Dym, 1994a).

Instituting well-designed freshman design courses has a number of practical advantages, as several institutions have already recognized (Sheppard et al., in press). Such courses give students more immediate contact with engineering faculty and provide context, that is, a cognitive tree on which to hang the education that follows. Students will get a good view of some part of engineering practice, so it may increase the retention rate for those whose desire to study engineering is sapped by a 2-year introduction to science. Even more important, project-based design courses offer students the opportunity to learn to work in teams, and to work toward satisfying a client, and thus to see first-hand that "engineering is a social activity"2 (Leifer, 1996). Perhaps most

\footnotetext{
${ }^{2}$ Personal communication.
}

important, such courses form a foundation for the rest of the engineering curriculum, especially when they are reinforced by design courses in the sophomore and junior years, as well as the senior capstone course.

Thus, design should be the cornerstone of engineering education, as well as a capstone (P. Little, personal communication, April 11, 1997). I don't have the space to suggest here how all engineering curricula should be revamped toward the goal of providing real design courses and experiences throughout the curriculum. But that ought to be the "prime directive" of designing engineering curricula for the future. And with that goal in mind, let us think about the role that design centers can play in propagating design education throughout the curriculum.

\section{THE ROLE OF DESIGN CENTERS IN ENGINEERING CURRICULA}

Centers of all stripes are widely evident across the American educational landscape. In engineering schools, centers are often devoted to specific technologies and, far more often than not, they are oriented to research and, consequently, to training graduate students. In the design area, among the most noteworthy with which I am familiar are the Engineering Design Research Center (EDRC) at Carnegie Mellon University (CMU) and Stanford's Center for Design Research (CDR) and Center for Integrated Facility Engineering (CIFE). EDRC is the oldest, and it has its roots in a Center for Design Research, founded at CMU in 1974, that articulated a cross-disciplinary approach to design that would transcend specific branches of engineering, and would describe and model design tasks whether or not they could be implemented in computer codes (Fenves, 1973). (We might note that this formulation was set forth at a time when our ability to model both concepts and tasks in computers was much more constrained than it is now.) This effort led to the establishment of the EDRC in 1986, with sponsorship from the National Science Foundation as part of its program of establishing large-scale centers that would do research to help American industry be more competitive (Fenves, Talukdar, et al., 1990).

The two Stanford centers were founded more recently, albeit with far less government research support, in fact with most of their support coming from industry. However, they were also set up as research centers whose primary aim was to bring to industry the fruits of advanced academic research, with the recognition that industry's involvement in that research would symbiotically enhance it.

All three centers have had significant impact on graduate education in their institutions. There also have been benefits at the undergraduate level as center-related faculty have offered new versions of old courses or entirely new courses. However, it is hard to identify major curricular changes that have emerged from these and other centers (and, to be fair, this was not part of their original charters).

So, it is worth asking, Is there a role for a center for design education that would work toward making design the 
backbone of engineering education? For its intellectual agenda, such a center would focus on stimulating an increased awareness of and the integration of the different design languages and representations by engineering faculty and students alike. This effort would be built in part on models of integrated design tools (Deitz, 1997; Dym \& Levitt, 1991; Fenves, Flemming, et al., 1990; Fischer \& Kunz, 1997) and in part on the circle of ideas outlined above. Thus, in short, the agenda of such a center would be to move engineering education from its reliance on mathematical modeling as the lingua franca of engineering toward much broader notions of engineering and design modeling.

As a practical matter, such a center would work toward the integration of design throughout the curriculum by offering course materials, developing computational tools for instructional use (e.g., for building objectives trees and morphological charts for conceptual design, for doing detailed design and optimization, etc.), sponsoring workshops and symposia for faculty who wanted to broaden their course offerings, and offering a meeting place for faculty and engineers from industry to talk about how design could be better taught in undergraduate curricula.

Obviously, my HMC colleagues and I believe that such a Center for Design Education is a good, viable idea-at the very least for our community. We invite your thoughts on this, as well as on roles you think that you and we could play in making a national agenda plausible and meaningful.

\section{ACKNOWLEDGMENTS}

I am grateful to some of my HMC colleagues for reading drafts of this paper, including Pat Little, who whetted it on his philosopher's stone through several versions, Zee Duron, Bill Purves, and Erik Spjut.

\section{REFERENCES}

ABET's web site: http://www.abet.ba.md.us/.

Deitz, D. (1997). The convergence of design and analysis. Mechanical Eng. 119 (3), 93-100.
Dixon, J.R. (1987). On research methodology towards a scientific theory of design. AIEDAM 1 (3).

Dixon, J.R. (1991a). The state of education. Mechanical Eng. 113 (2).

Dixon, J.R. (1991b). New goals for engineering education. Mechanical Eng. 113 (3).

Dym, C.L. (1992a). Letter to the editor. Mechanical Eng. 114 (8).

Dym, C.L. (1992b). Representation and problem solving: The foundations of engineering design. Plann. Design: Environ. Plann. B, 19, 1992, $97-105$.

Dym, C.L. (1993). The role of symbolic representation in engineering design education. IEEE Trans. Educ. 36 (1), 187-193.

Dym, C.L. (1994a). Teaching design to freshmen: Style and content. J Eng. Educ. 83 (4), 303-310.

Dym, C.L. (1994b). Engineering Design: A Synthesis of Views. Cambridge University Press, New York.

Dym, C.L. (1994c). Representing designed objects: The languages of engineering design. Arch. Computational Methods Eng. 1 (1), 75-108.

Dym, C.L., \& Levitt, R.E. (1991). Toward the integration of knowledge for engineering modeling and computation. Eng. Computers 7 (4), 209-224.

Evans, D.L. (1990). Special issue: Integrating design throughout the curriculum. Eng. Educ. 80 (5)

Fenves, S.J. (1973). Inter-Office memorandum to H.A. Simon, Carnegie Mellon University, 30 July 1973.

Fenves, S.J., Flemming, U., Hendrickson, C., Maher, M.L., \& Schmitt, G. (1990). Integrated software environment for building design and construction. Computer-Aided Design 22 (1), 27-36.

Fenves, S.J., Talukdar, S., \& Westerberg, A.W. (1990). Summary Report to the Alfred P. Sloan Foundation, EDRC, Carnegie Mellon University, 12 November 1990.

Fischer, M., \& Kunz, J. Circle integration. CIFE Working Paper No. 20, Center for Integrated Facility Engineering, Stanford University, 9 April 1997.

Phillips, J.R. (1994). Engineering clinic issues. Proc. 30th Anniversary Symp., Harvey Mudd College.

Harvey Mudd Catalog (1996-1998). Harvey Mudd College, Claremont, CA.

Leifer, L. I believe Stanford's Larry Leifer was the first to articulate this phrase.

Lih, M.M. (1997). Educating future executives. ASEE Prism.

Phillips, J.R., \& Gilkeson, M.M. (1991). Reflections on a clinical approach to engineering design. Proc. Int. ASME Conf. Design Theory Methodol.

Sheppard, S.D. (1996). Thoughts on freshman engineering design experiences. Symp. Eng. Educ. 21st Century.

Sheppard, S.D., Jenison, R. et al. (in press). Examples of freshman design education. Int. J. Eng. Educ.

Shoup, T.E. et al. (1993). Innovations in engineering design education. ASME Design Educ. Conf.

Simon, H.A. (1981). The Sciences of the Artificial. MIT Press, Cambridge, MA. 